\title{
THE EFFECT OF BACLOFEN ON SPONTANEOUS AND EVOKED BEHAVIOURAL EXPRESSION OF EXPERIMENTAL NEUROPATHIC CHRONIC PAIN
}

\author{
TEREZINHA DE JESUS T. SANTOS*, CARLOS M. DE CASTRO-COSTA**, SILVIO D. A. GIFFONI***, \\ FRANKLIN J. C. SANTOS ${ }^{* *}$, RODRIGO S. N. RAMOS ${ }^{* * *}$, MARCUS A. C. GIFONI****
}

\begin{abstract}
Baclofen ( $\beta$-p-chlorophenyl-GABA) has been used in humans to treat spasticity, as well as trigeminal neuralgia. Since GABA (gamma-aminobutyric acid) has been implicated in inhibitory and analgesic effects in the nervous system, it was of interest to study the effect of baclofen in experimental neuropathic pain. With this purpose, experiments were carried out in 17 neuropathic rats with constrictive sciatic injury, as described by Bennet and Xie (1988), taking as pain parameters scratching behaviour and the latency to the thermal nociceptive stimulus. The results showed that baclofen induces, in a dose-dependent manner, significant decrease $(p<0.05)$ of scratching behaviour and significant increase $(\mathrm{p}<0.05)$ of the latency to the nociceptive thermal stimulus. The absence of antagonism of naloxone suggested a non-participation of an opioid-mediated mechanism in this analgesic effect of baclofen on experimental neuropathic pain.
\end{abstract}

KEY WORDS: baclofen, experimental neuropathic pain, Bennet's model, scratching behaviour, thermal stimulus, analgesia.

\section{Efeito do baclofeno sobre a expressão comportamental espontânea e evocada da dor crônica neuropática experimental}

RESUMO - O baclofeno ( $\beta$-p-clorofenil-GABA) é usado em seres humanos para tratar espasticidade, assim como neuralgia do trigêmeo. Como o GABA (ácido amino-gama-butírico) tem sido implicado em efeitos inibitórios e analgésicos no sistema nervoso, tornou-se de interesse estudar o efeito do baclofeno em dor neuropática experimental. Com esse objetivo, foram realizados experimentos em 17 ratos neuropáticos com lesão constritiva do nervo ciático, como descrito por Bennet e Xie (1988), tomando como parâmetros de dor o comportamento de coçar-se (scratching) e a latência ao estímulo térmico nociceptivo. Os resultados mostraram que o baclofeno induziu, de forma dose-dependente, diminuição significativa $(\mathrm{p}<0,05)$ do comportamento de coçar-se e aumento significativo $(\mathrm{p}<0,05)$ da latência ao estímulo térmico nociceptivo. A ausência de antagonismo pela naloxona sugere a não participação de mecanismo opióide-mediado nesse efeito analgésico do baclofeno em dor neuropática experimental.

PALAVRAS-CHAVE: baclofeno, dor neuropática experimental, modelo de Bennet, comportamento de coçar-se (scratching), estímulos térmicos, analgesia.

The study of neuropathic pain remains a serious challenge, since its underlying mechanisms have not yet been elucidated and consequently there is currently a lack of effective treatment. Among the different attempts to alleviate this kind of chronic pain in humans, baclofen ( $\beta$-p-chlorophenyl-

Laboratory of Experimental Neurology (Department of Physiology and Pharmacology), Federal University of Ceará (UFC) Brazil: *Pharmacist, MsC; **MD, MsC, PhD; ***MD; ****Student. This research was supported by a CNPq grant. Aceite: 19-junho-1999.

Dra. Terezinha de Jesus Teixeira Santos - Laboratório de Neurologia Experimental, Departamento de Fisiologia e Farmacologia/UFC - Rua Cel. Nunes de Melo 1127 - 60430-270 Fortaleza CE - Brasil. Fax 55852439333 
GABA) has been used for the treatment of trigeminal neuralgia, human post-herpetic neuralgia ${ }^{1}$ and more recently, of post-ictal pain ${ }^{2}$, diabetic painful neuropathy ${ }^{3}$ and central pain of spinal origin ${ }^{4}$. Experimentally, this analgesic effect of baclofen has been demonstrated in animal acute pain. Smith et al. ${ }^{5}$ have shown an antinociceptive activity of baclofen in rats with chronically evoked hyperalgesia induced by experimental neuropathic (constrictive sciatic injury), but not by inflammatory (adjuvant - arthritis) conditions. On the other side, baclofen has also shown to exert hyperalgesia effects, when administered in high doses with microinjections in the ventral medulla of rats $^{6,30}$.

Since these studies did not approach a long-term analysis of spontaneous behavioural expression of chronic neuropathic conditions, we have aimed at defining the antinociceptive effect of baclofen on pain-related behaviour, coupled with evoked expressions of them.

\section{METHOD}

\section{Animals}

Thirty-three male Wistar rats, weighting 250-300g, were used. The animals were distributed in groups of four rats per cage, with water and food ad libitum; they were kept with environmental light and temperature of $25 \mathrm{oC}$. The animals were divided into two control groups: normal $(\mathrm{n}=8)$ and sham-operated $(\mathrm{n}=8)$, and into two surgical experimental groups $(\mathrm{n}=10$ and $\mathrm{n}=7)$.

\section{Surgery}

For reproduction of the neuropathic model, the method of Bennet and $\mathrm{Xie}^{7}$ has been followed: the rats were anesthetized with hypnorm (fluanisonum $10 \mathrm{mg}$ + fentanylum $0.2 \mathrm{mg} / \mathrm{ml}$ ) in a dosage of $1 \mathrm{ml} / 100 \mathrm{~g}$ of body weight, injected in the hindlimb, intramuscularly. After transecting the fascia between the gluteus and biceps femoris nerve, the right common sciatic nerve was exposed at the level of the midthigh, proximal to its trifurcation, and the nerve was carefully dissected from its surrounding tissue over a distance of about $8 \mathrm{~mm}$. In the experimental group, four ligatures were loosely tied around the common sciatic nerve with sterile non-inflammatory mononylon 4.0 thread. This latter procedure differed somewhat from the original description ${ }^{7}$. As a control, the left sciatic nerve was similarly exposed, but not ligated or touched. This procedure was also done for the sham-operated animals, where the sciatic nerve was similarly exposed, but not ligated, on both sides.

\section{Observations of spontaneous behaviour}

The observations of the spontaneous (stress-free) behaviour were performed as previously described by De Castro-Costa et al. ${ }^{8}$ and Kupers et al. ${ }^{9}$. The rats were then placed in a faintly illuminated observation cage $(100 \times 50 \times 50 \mathrm{~cm})$ with the floor covered with wood shavings. The cage was placed in a darkened and silent room. The front of the cage was made of glass, which permitted the experimenter to observe the behaviour elements. After an adaptation period of five minutes, the observations started. During a period of 30 minutes, the behaviour of the rat was systematically recorded by immediately pressing one of the keys of a keyboard, corresponding to the various elements of the rat's behaviour. The keyboard was connected to a computer, which stored the data. The following behaviour were recorded: freezing, rearing, sniffing, grooming, eating, rest/sleeping and scratching with right or left hindpaw towards the head, flank or the air.

\section{Observations of evoked behaviour (thermal tests)}

This test, as described by Attal et al. ${ }^{10}$, consisted of immersing the hindlimbs of the rats into water heated from $40^{\circ} \mathrm{C}$ to $46^{\circ} \mathrm{C}$. The rat was carefully manipulated by the experimenter and wrapped in a towel so that its extended hindpaws and head were free. Each extended hindpaw was then immersed, and the struggle and paw flick latency reaction of the animal was observed and recorded by the use of a chronometer. A cut-off period of 15 seconds was established for these tests, and we selected $40^{\circ} \mathrm{C}$ for non-noxious and $46^{\circ} \mathrm{C}$ for noxious stimuli.

\section{Pharmacological tests}

For the pharmacological tests, baclofen and naloxone were used. Baclofen (Lioresal - Ciba Geigy Basel - Switzerland) is a spinal antispastic drug with rapid and complete gastrointestinal absorption, with maximum serum concentration after 30-90 minutes and distribution volume of $0.71 / \mathrm{kg}$. Its half-live is three to four hours, and it is 30\% protein-bound. Its has mostly renal excretion (75\% in 72 hours) and $5 \%$ is excreted in the faeces. Its inactive metabolite is $\beta$ (p-chlorophenyl) gamma-hydroxybutyric acid. Baclofen ( $\beta$-p-chlorophenyl-GABA) in doses of 1,2, 4 and $8 \mathrm{mg} / \mathrm{kg}$, per os, was used. The behavioural observations and thermal tests were done after two hours from administration, since motor effects of baclofen are significant from 10 to 120 minutes after 
administration. Naloxone was used, intraperitoneally, in a dose of $2.5 \mathrm{mg} / \mathrm{kg}$, and the behavioural observations and thermal tests were begun immediately after its administration, since its has a short duration of action.

For the control groups, saline was used in the same route and quantity. The pharmacological were preceded by pre-observation of the behaviour in non-drug condition.

\section{Statistical analysis}

Results are expressed as the mean \pm S.E.M. and were analyzed by an analysis of variance (ANOVA). For individual comparisons between means of the behaviour and thermal latencies, the Tukey test was used. For nonnormally distributed related and independent samples, the non-parametric Wilcoxon matched-pairs signed-rank and the Mann-Whitney $\mathrm{U}$ tests were used, respectively. Results were regarded as being significant when $\mathrm{p}$ values were lower than 0.05 .

The ethical requirements of IASP ${ }^{11}$ have been followed: The duration of the experiments was as short as possible, and the number os animals used was kept to a minimum.

\section{RESULTS}

The behavioural analysis of the experimental rats showed a significant increase $(p<0.05)$ of the scratching behaviour from the 2 nd post-operative day up to four months, defining the chronic condition (Fig. 1). This significant increase predominated in the right-lesioned side, but a significant increase was also detected in the left hindlimb, as compared with controls (Table 1).

This was correlated with a parallel significant decrease of latency of the hindlimb withdrawal to non-noxious stimulus of $40^{\circ} \mathrm{C}$, thus showing the presence of allodynia in the right-lesioned hindlimb (Fig. 2).

The results with noxious $\left(46^{\circ} \mathrm{C}\right)$ stimulus, however, did not indicate hyperalgesia, possibly due to deafferentation hypoalgesia in the right hindlimb.

Baclofen, in a dose-dependent way, depressed significantly $(\mathrm{p}<0.05)$ the scratching behaviour in the experimental animals (Fig. 3) as compared with the sham-operated animals with saline. The

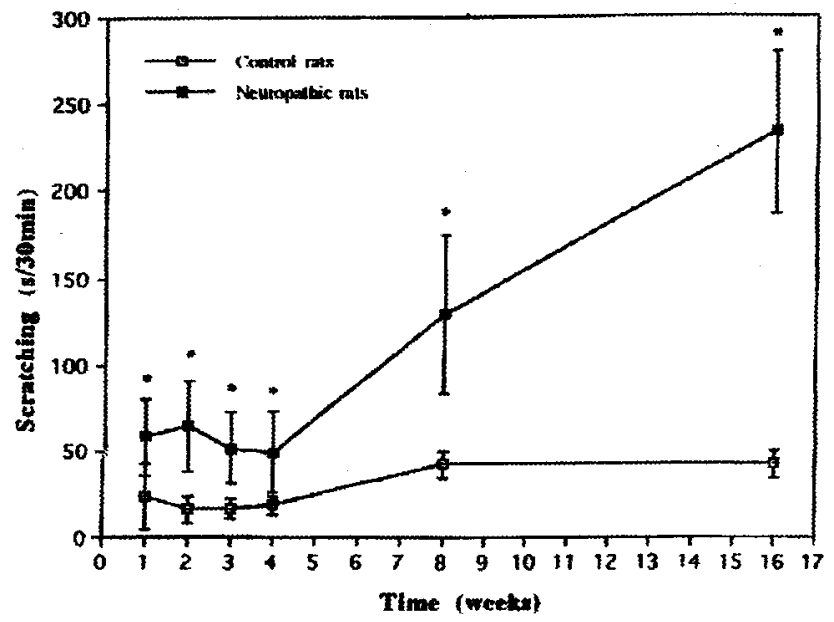

Fig 1. Time course of scratching in neuropathic $(n=8)$ and sham-operated rats $(n=8)$. The scratching behaviour is significantly $(p<0.05)$ increased up to the 16th week. Values are expressed as the mean \pm S.E.M. Analysis of Variance - ANOVA. (Tukey and Mann-Whitney U tests). 
Table 1. Effect of baclofen (4 and $8 \mathrm{mg} / \mathrm{kg}$, per os) on the behaviour of neuropathic rats $(n=10)$

\begin{tabular}{lcccccccc}
\hline Behaviour & \multicolumn{3}{c}{ With Saline } & \multicolumn{2}{c}{ With Baclofen $4 \mathrm{mg} / \mathrm{kg}$} & \multicolumn{3}{c}{ With Baclofen 8 mg/kg } \\
& $\mathrm{X}$ & SEM & $\mathrm{X}$ & SEM & $\mathrm{P}$ & $\mathrm{X}$ & SEM & $\mathrm{P}$ \\
\hline Freezing & 19.8 & 7.4 & 153.5 & 58.0 & $<0.02$ & 127.6 & 40.3 & NS \\
Rearing & 27.7 & 10.4 & 7.4 & 2.7 & NS & 0.0 & 0.0 & $<0.05$ \\
Sniffing & 357.7 & 135.1 & 203.0 & 76.7 & NS & 178.7 & 56.5 & NS \\
Grooming & 307.2 & 116.1 & 717.2 & 271.0 & $<0.05$ & 42.5 & 13.4 & $<0.02$ \\
Scratching (total) & 190.0 & 71.8 & 82.2 & 31.0 & $<0.02$ & 0.0 & 0.0 & $<0.02$ \\
Scratching (right hindlimb) & 96.5 & 36.4 & 35.5 & 13.4 & $<0.05$ & 0.0 & 0.0 & $<0.05$ \\
Scratching (left hindlimb) & 93.4 & 35.3 & 46.7 & 17.6 & NS & 0.0 & 0.0 & $<0.05$ \\
Eating & 157.8 & 59.6 & 95.7 & 36.1 & NS & 575.4 & 181.9 & $<0.02$ \\
Rest/Sleeping & 655.1 & 247.6 & 489.0 & 184.8 & NS & 1138.8 & 360.1 & NS \\
\hline
\end{tabular}

NS, not significant.

exploratory motor behaviour, such as sniffing, was not significantly changed by baclofen. Other behaviour (eating and rest/sleeping) did not vary significantly (see Table 1 ). In the thermal tests, baclofen, in different doses $(1,2$ and $4 \mathrm{mg} / \mathrm{kg})$, increased significantly $(\mathrm{p}<0.01)$ the threshold of hindlimb withdrawal to non-noxious $\left(40^{\circ} \mathrm{C}\right)$ and noxious $\left(46^{\circ} \mathrm{C}\right)$ stimuli (Fig. 4$)$, and this paralleled its significant depression of scratching behaviour (see above).

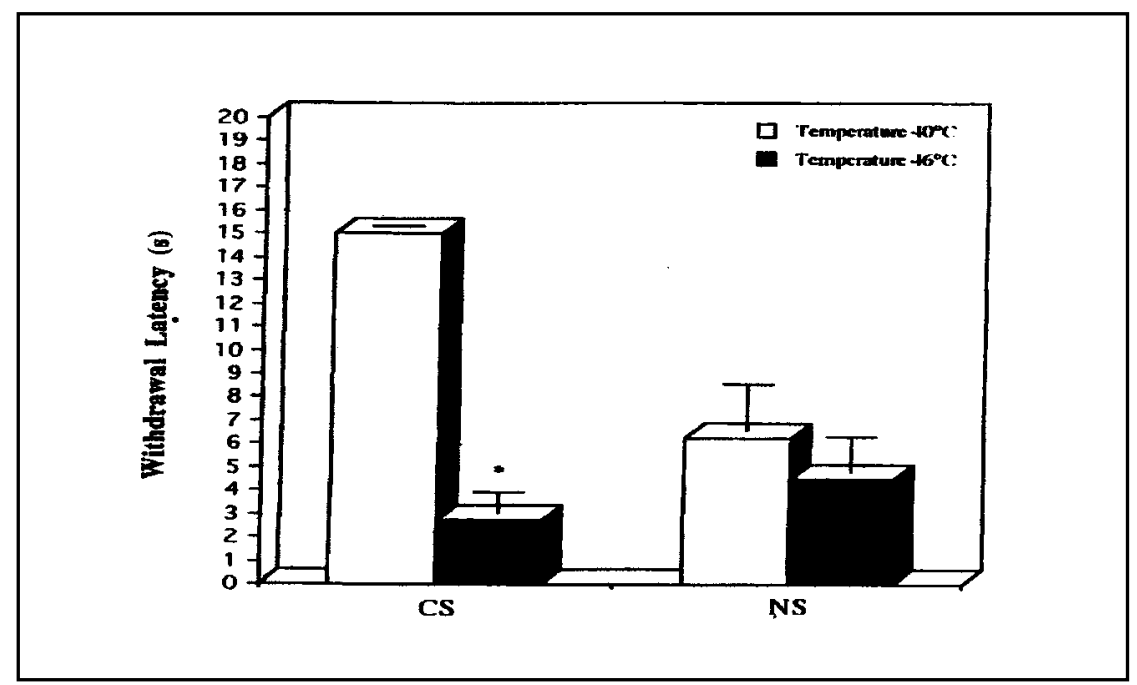

Fig 2. Withdrawal latency of the right hindlimb to thermal stimulus of $40^{\circ} \mathrm{C}$ and $46^{\circ} \mathrm{C}$ in neuropathic $(n=8)$ and sham-operated rats $(n=8)$. The neuropathic rats showed a significantly $(p<0.01)$ decreased threshold to non-noxious thermal stimulus of $40^{\circ} \mathrm{C}$ (allodynia). Values are expressed as the mean \pm S.E.M. (Tukey test). These tests were carried out in the 3rd post-surgical months (CS: Control rats with Saline; NS: Neuropathic rats with Saline). 


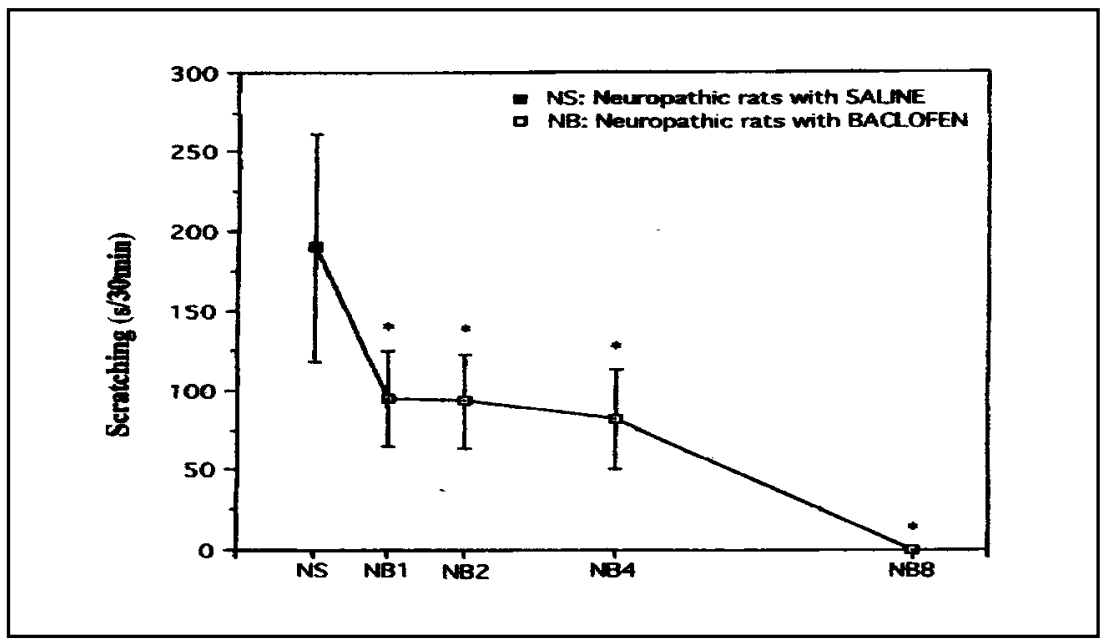

Fig 3. Baclofen decreases significantly ( $p<0.05)$, in a dose-dependent manner $(1,2,4$ and $8 \mathrm{mg} / \mathrm{kg}$, per os), the scratching behaviour of neuropathic rats $(N B)$ as compared with the same animals injected with saline (NS). Values are expressed as the mean \pm S.E.M. (Wilcoxon matched-pairs signed-ranks test). These tests were carried out between the 3rd and 6th post-surgical months.

These effects of baclofen on scratching and latency of hindlimb withdrawal to thermal stimuli were not reversed by naloxone.

Clinically only four animals exhibited autotomy, although there was not a consistent correlation between autotomy and the increased scratching and/or allodynia.

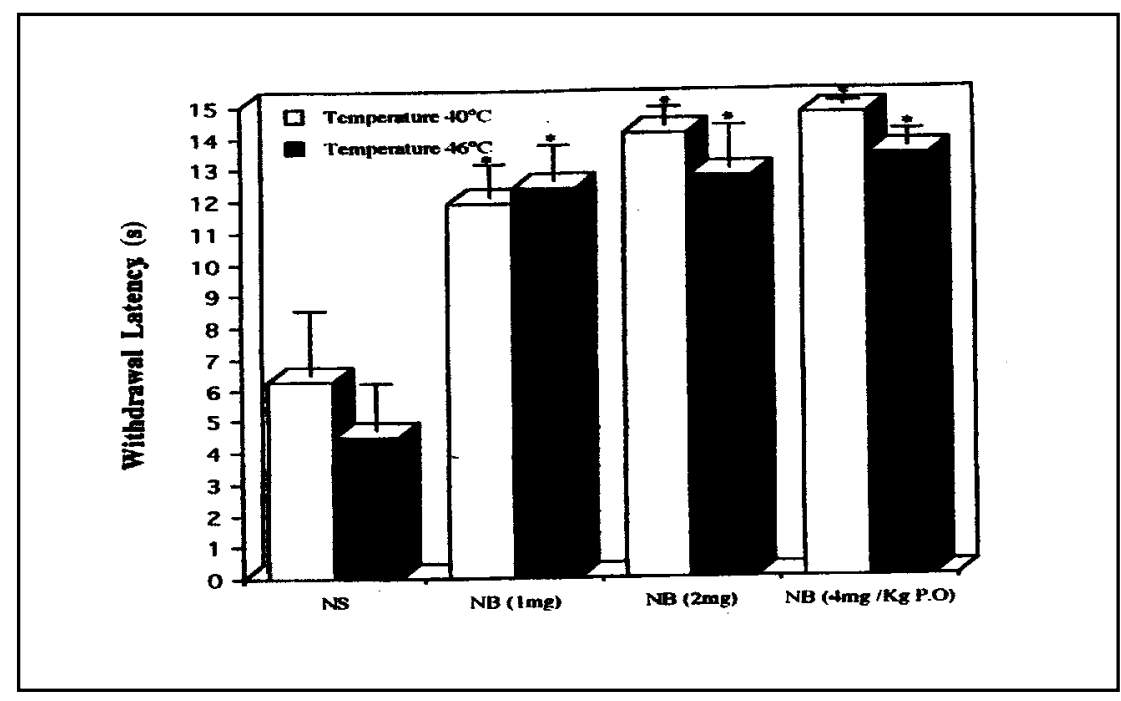

Fig 4. Baclofen (1, 2 and $4 \mathrm{mg} / \mathrm{kg}$, per os) increases significantly $(p<0.01)$ the withdrawal latency of the right hindlimb of neuropathic rats $(n=8)$ to non-noxious $\left(40^{\circ} \mathrm{C}\right)$ and noxious $\left(46^{\circ} \mathrm{C}\right)$ thermal stimulus. Values are expressed as the mean \pm S.E.M. (Tukey test). These tests were carried out between the $3 r d$ and 6th post-surgical months (NS: Neuropathic rats with Saline; NB: Neuropathic rats with Baclofen). 


\section{DISCUSSION}

One of the objectives of this study was to define the analgesic effect of baclofen on the stressfree, spontaneous behavioural expression of an experimental neuropathy. In human neuropathies, such as pellagra, diabetes, amyloidosis and malnutrition, spontaneous and/or evoked expressions of neuropathic pain are frequent. The mechanisms responsible for these kinds of pain in neuropathies are not well understood, but abnormal activity of nociceptors and central neurons seems to be implicated. While hyperalgesia and allodynia are evoked by triggers, spontaneous pain waxes and wanes without an evoking factor. In patients this may be verbally expressed, but in animals can be only detected by long-term observation of subtle spontaneous behavioural changes. In order to reinforce a possible nociceptive involvement in this spontaneous expression, the behaviour changes must be coupled with tests that permit the detection of allodynia and/or hyperalgesia.

In previous reports, it has been shown that scratching behaviour may be a sign of chronic pain in inflammatory $8,12,13$ and in neuropathic models ${ }^{9}$. This has been reproduced in our experiments, where scratching behaviour has been shown to be significantly and chronically increased in the right-lesioned hindlimb of neuropathic animals (Fig 1). It was also significantly increased in the left sham-operated hindlimb, possibly as a manifestation of "mirror pain", similar to findings in animals injected with formalin described by Alloisi et al. ${ }^{14}$.

In addition to this spontaneous behavioural expression of neuropathic pain in our animals, thermal allodynia was also found, reinforcing the nociceptive relevance of the abnormally increased scratching behaviour (Fig. 2). This corroborates previous findings on the correlation between increased scratching and allodynia in neuropathic animals ${ }^{9}$. Moreover, the putative significance of scratching behaviour as a sign of pain has been substantiated by: (1) its evocation induced by excitatory neurotransmitters and substances $^{15}$; (2) the positive correlation between its increase and the augmentation of substance $\mathrm{P}$ in the spinal cord ${ }^{16}$; and (3) its depression by morphine ${ }^{8,12}$ and thalamic electrical stimulation ${ }^{13}$.

Baclofen, in a dose-dependent fashion, depressed significantly the spontaneous scratching behaviour and evoked expression of neuropathic pain (allodynia) in these animals (Figs. 3 and 4). This adds further support to a report on the antinociceptive effect of baclofen on evoked symptoms (mechanical allodynia) in neuropathic animals ${ }^{5}$ and on a rat model of trigeminal neuropathic pain ${ }^{17}$. However, Castro-Lopes et al. ${ }^{18}$ reported on a significant fall in the number of GABA-immunoreactive cells in laminae I-III of the rat spinal cord, after sciatic nerve transection. In Bennet's model, however, only a partial lesion is present, and besides the possible partial depletion of $\mathrm{GABA}_{\mathrm{B}}$ receptor induced by the lesion, if any, a compensating up-regulation may hypothetically occur. The absence of this depleting effect on $\mathrm{GABA}_{\mathrm{B}}$ receptors has been shown by Smith et al. ${ }^{5}$ in Bennet's model. Moreover, they found an analgesic effect of baclofen in neuropathic rats and an absence of it in inflammatory rats, the significance of which is unclear. The mechanisms involved in this analgesic effect of baclofen are not yet defined. Saito et al. ${ }^{19}$ suggested that it may occur by an antagonism to substance P. Other authors suggested that it could be explained by pre-synaptic inhibition of primary afferents or by inhibition of neurotransmitter release from primary afferents ${ }^{20}$, or by involvement of noradrenergic ${ }^{21}$ or by cholinergic mechanisms ${ }^{22}$. The analgesic action of baclofen and morphine seems to involve, at least in part, common neural substrates located somewhere in the pons and anterior third of the medulla ${ }^{23 .}$ However, the active sites in the brainstem differ from that of morphine ${ }^{24}$. On the other hand, Cui et al. ${ }^{25}$ have recently shown that spinal cord stimulation exerts its analgesic effect by an activation of local GABA-ergic mechanisms, inhibiting excitatory aminoacid release, thus reinforcing the notion of GABA participation in spontaneous and evoked analgesia.

Moreover, in support of its analgesic action, baclofen has been shown to exert a significant, dose-dependent reduction of carrageenan-induced spinal c-Fos expression ${ }^{26}$.

Although we did not intend primarily to study the mechanisms underlying the antinociceptive effect of baclofen, part of our results have suggested a non-participation of the opioid system in its 
action, corroborating similar findings previously reported by Levy and Proudfit ${ }^{27}$. Possibly, an upregulation of cholecystokinin (CCK-8) in neuropathic conditions may also be implicated in this non-opioid effect, since it is known that the opioid system may be endogenously antagonized by CCK, normally present and released in the spinal $\operatorname{cord}^{28}$.

An important aspect to resolve is the differentiation of the antinociceptive from the motor effect of baclofen, since this drug was first recognized as an effective antispastic drug. As shown in the Table 1, other motor exploratory activities were not depressed with a dose of $4 \mathrm{mg} / \mathrm{kg}$. At a higher dose ( $8 \mathrm{mg} / \mathrm{kg}$ ), the self-directed behaviour (scratching and grooming) was mostly decreased. However, even at these doses, other motor activities (sniffing while walking) were not totally reduced. Similarly, Cutting and Jordan ${ }^{29}$ did not find evidence of motor impairment in mice with low doses of baclofen. This impairment was not reinforced with morphine association; moreover, the sedative effect of baclofen in high doses, a side effect usually complained of by patients, was not prominent in the animals. Baclofen was administered in the present study via the oral route and give results similar to those of other authors who used the intraperitoneal or subcutaneous route 5 . It is known that baclofen is absorbed rapidly after oral administration, reaching maximal plasmatic concentrations after 0.5 to 1.5 hours, with a half-life of three to four hours. We used baclofen doses in a ranging from 1 to $8 \mathrm{mg} / \mathrm{kg}$. According to Proudfit and Levy ${ }^{23}$, in rats with transection of the cerebrospinal axis, a $5 \mathrm{mg} / \mathrm{kg}$ dose of baclofen induced no discernible delay in the response, while a dose of 7.5 $\mathrm{mg} / \mathrm{kg}$ did. On the other hand, Thomas et al..$^{30}$ reported an antinociceptive effect of low doses in comparison with the hyperalgesia induced by high doses.

In conclusion, our study has shown that scratching behaviour, as a spontaneous expression of chronic experimental neuropathic pain, is depressed by baclofen in a dose-dependent fashion. This is also reinforced by the alleviating effect of baclofen on allodynia shown in these animals. The baclofen effect on both scratching and allodynia seems to be an analgesic action, since motor behaviour was not reduced significantly. In addition, this antinociceptive effect of baclofen seems not to involve an opioid mechanism.

Acknowledgements - The authors would like to thank Professor Jan Gybels for reading the draft of this manuscript and providing us with valuable suggestions and comments, Professor Odorico de Moraes for his technical assistance, Doctor David Neil Criddle who kindly revised the English structure of the text and Mr. Sílvio Costa for his accurate typewriting of the manuscript in a wordprocessor.

\section{REFERENCES}

1. Terrence CF, Fromm GH, Tenicela R. Baclofen as an analgesic in chronic peripheral nerve disease. Eur Neurol 1985;24:380-385.

2. Taira T, Tanikawa T, Kawamura H et al. Spinal intrathecal baclofen suppresses central pain after a stroke. J Neurol Neurosurg Psychiatry 1994;57:381-386.

3. Anghinah R, Oliveira ASB, Gabbai AA. Effect of baclofen on pain in diabetic neuropathy. Muscle \& Nerve 1994;17:958-959.

4. Herman RM, D'Luzansky SC, Ippolito R. Intrathecal baclofen suppresses central pain in patients with spinal lesions. Clin J Pain 1992;8:338-345.

5. Smith GD, Harrison SM, Birch PJ et al. Increased sensitivity to the antinociceptive activity of ( \pm ) baclofen in an animal model of chronic neuropathic, but not chronic inflammatory hyperalgesia. Neuropharmacology 1994;33:1103-1108.

6. Hammond DL, Nelson V, Thomas DA. Intrathecal methysergide antagonizes the antinociception, but not the hyperalgesia produced by microinjection of baclofen in the ventro-medial medulla of the rat. Neurosci Lett 1998;244:93-96.

7. Bennet GJ, Xie YK. A peripheral mononeuropathy in rat that produces disorders of pain sensation like those seen in man. Pain 1988;33:87-107.

8. De Castro-Costa CM, De Sutter P, Gybels J et al. Adjuvant induced arthritis in rats: a possible animal model of chronic pain. Pain 1981;10:173-185.

9. Kupers R, Nuytten D, De Castro-Costa CM et al. A time course analysis of the spontaneous and evoked behaviour in a rat model of neuropathic pain. Pain 1992;50:101-111.

10. Attal N, Jazat F, Kayser V et al. Further evidences for pain-related behaviours in a model of unilateral peripheral mononeuropathy. Pain 1990;41:235-251.

11. IASP, Committee for Research and Ethical Issues. Ethical standards for investigation of experimental pain in animal. Pain 1983;16:109-110.

12. De Castro-Costa CM, Gybels J, Kupers R, et al. Scratching behaviour in arthritic rats: a sign of chronic pain or itch? Pain 1987;29:123-131. 
13. Kupers R, Vos B, Gybels J. Stimulation of the nucleus paraventricularis thalami suppresses scratching and biting behaviour of arthritic rats and exerts a powerful effect on tests for acute pain. Pain 1988;32:115-125.

14. Alloisi AM, Porro CA, Cavazzuti M, et al. "Mirror pain" in the formalin test: behavioural and 2-deoxyglucose studies. Pain 1993;55:267-273.

15. Dobry PJK, Piercey MF, Schroeder I. Pharmacological characterization of scratching behavior induced by intracranial infection of substance P and somatostatin. Neuropharmacology 1981;20:267-272.

16. Schoenen J, Van Hess J, Gybels J, et al. Histochemical changes of substance P, FRAP, serotonin and succinic dehydrogenase in the spinal cord of rats with adjuvant arthritis. Life Sci 1985;36:1247-1254.

17. Idänpään-Heikkilä JJ, Guilbaud G. Pharmacological studies on a rat model of trigeminal neuropathic pain: baclofen, but not carbamazepine, morphine or tricyclic antidepressants, attenuates the allodynia-like behaviour. Pain 1999;79:281-290.

18. Castro-Lopes JM, Tavares I, Coimbra A. GABA decreases in the spinal cord dorsal horn after peripheral neurectomy. Brain Res 1993;620:287-291.

19. Saito K, Konish S, Otsuka M. Antagonism between lioresal and substance P in rat spinal cord. Brain Res 1975;97:177-180.

20. Fox S, Krnjevic K, Morris ME, et al. Action of baclofen on mammalian synaptic transmission. Neuroscience 1978;3:495-515.

21. Sawynok J, Reid A. Role of ascending and descending noradrenergic pathways in the antinociceptive effect of baclofen and clonidine. Brain Res 1986;386:341-350.

22. Kendal DA, Browner M, Enna SJ. Comparison of the antinociceptive effect of gamma-aminobutyric acid (GABA) agonists: evidence for a cholinergic involvement. J Pharmacol Exp Therap 1982;220:482-487.

23. Proudfit HK, Levy RA. Delimitation of neuronal substracts necessary for the analgesic action of baclofen and morphine. Eur J Pharmacol 1978;47:159-166.

24. Levy RA, Proudfit HK. Analgesia produced by microinjection of baclofen and morphine at brainstem sites. Eur J Pharmacol 1979;57:43-55.

25. Cui J-G, O'Connor WT, Ungerstedt U, et al. Spinal cord stimulation attenuates augmented dorsal horn release of excitatory aminoacids in mononeuropathy via a GABA-ergic mechanism. Pain 1997;53:87-95.

26. Buritova J, Chapman V, Honoré $\mathrm{P}$, et al. The contribution of GABAB receptor-mediated events to inflammatory pain processing: carrageenan edema and associated spinal c-Fos expression in the rat. Neuroscience 1996;73:487-496.

27. Levy RA, Proudfit HK. The analgesic action of baclofen [BETA- (4-chlorophenyl) gamma-aminobutyric acid]. J Pharmacol Exp Therap 1977;202:437-445.

28. Baber NS, Dourish CT, Hill DR. The role of CCK, caerulein, and CCK antagonists in nociception. Pain 1989;39:307-328.

29. Cutting DA, Jordan CC. Alternative approaches to analgesia: baclofen as a model compound. Br J Pharmacol 1975;54:171-179.

30. Thomas DA, McGowan MK, Hammond DL. Microinjection of baclofen in the ventromedial medulla of rats: antinociception at low doses and hyperalgesia at high doses. J Pharmacol Exp Therap 1995;275:275-284. 